\title{
Mind the gap: school librarians' anticipated and preferred professional development methods for integration of digital textbooks
}

\author{
Ji Hei Kang \\ Florida State University \\ 142 Collegiate Loop, Tallahassee, FL 32306 \\ USA \\ jk11e@my.fsu.edu
}

\begin{abstract}
While the mandate to adopt digital textbooks in the U.S. state of Florida is looming for the next school year, there has been few discussion about how to provide professional development for school librarians who will be expected to play a leadership role. This study identifies both preferred and anticipated methods of professional development of Florida school librarians and the gap between them. It has been found that school librarians wish to initiate their training with other colleagues through workshops and study groups, which will enable them to discuss digital textbooks, and build networks with respect to the new technology. The anticipated way, however, reflects the environment of solo librarians. In conclusion, this study urges that professional development that will enlarge their viewpoint and enhance their awareness of the need for methods of implementation of digital textbooks, is urgently required.
\end{abstract}

Keywords: professional development, digital textbooks, school librarian

\section{Introduction}

The comprehensive adoption of digital technology has led to the exploration of digital textbook initiatives: twelve states in the U.S. (Fletcher, Schaffhauser, \& Levin, 2012), and such countries as Denmark, Hong Kong, Japan, Singapore, and South Korea have initiated digital textbook projects (Kampylis et al., 2013). This trend is projected to expand (Murray \& Perez, 2011): by the 2015-2016 school year, it will be mandatory in Florida to use only digital textbooks for public schools from kindergarten through grade twelve $(\mathrm{K}-12)$ (The Florida Senate, 2011).

With this mandate, school librarians are expected to play a leadership role in integrating technology into schools while also taking charge of various traditional tasks (Everhart, Mardis, \& Johnston, 2012; Johnston, 2012; Perez, 2013). In order to help school librarians be leaders in implementing digital textbooks, it is essential for them to have opportunities for 
professional development. There should be wider discussion about such professional development, as various factors impact how educators integrate technology, including content, depth, and delivery format (Claesgens et al., 2013; Hixon \& Buckenmeyer, 2009). Empirical research to identify professional development for digital textbook implementation is not present in the literature. As an initial step, this exploratory study identifies the methods of professional development that school librarians prefer and anticipate to educate themselves in digital textbook integration. This study also suggests an improved method to provide professional development tools by analyzing the gaps between the expected and anticipated.

\section{Literature Review}

School librarians have taken on various roles, such as leaders, instructional partners, information specialists, teachers, and program administrators (American Association of School Librarians, 2009). The new leadership roles for integrating technology in schools are still emerging for school librarians (Branch-Mueller \& De Groot, 2011; Everhart et al., 2012; Johnston, 2012; Lankford, 2006; Perez, 2013). School librarians are expected to increase instruction and services for learners, in addition to collaborating with teachers, counselors, and administrators to provide better access and promote information literacy (Perez, 2010).

Previous research asserts that professional development has been a valued approach for educators to continue learning about educational technology innovations. This in turn reinforces leadership development (Hixon \& Buckenmeyer, 2009; Muijs \& Harris, 2007), a key type of professional development for school librarians to integrate technology into schools (Johnston, 2012; Perez, 2010) and they have employed a variety of professional development methods such as traditional conferences, workshops, periodicals, and books. Yet school librarians are also using 21st century tools such as wikis, blogs, online learning communities, collaborative dialogue, and professional learning networks (Harvey, 2012; Starkey, 2012). After a recent radical restructuring of professional development channels, professional development tools can be customized and include free online webinars, livestreams, Twitter chats and podcasts. School librarians are encouraged for to use digital these tools (Foote, 2013), but the discussion about professional development for digital textbook implementation remains absent.

On the other hand, digital textbooks which may seem simple on the surface, have complex and unique features. Digital textbooks are now encompass "a reader, read-on-demand computer-based textbooks, print-on-demand digital textbooks, and modular assemblages of audio, visual, interactive, and text resources" (Mardis, Everhart, Smith, Newsum, \& Baker, 2010 , p. 3). This provides various interactive functions for students to study anytime and anywhere by containing "reference books, workbooks, learner's dictionaries, notebooks, and existing textbooks as well" (The Korea Education and Research Information Service (KERIS), 2009, para. 1). School librarians' will continue to implement their expert knowledge at "identifying, collecting, and organizing the best content" (Mardis et al., 2010, p. 14) and building open-content learning resources. They will also continue to collaborate with classroom teachers in the use of digital textbooks. 


\section{Data Collection}

In order to identify school librarians' anticipated and preferred professional development methods, the researcher conducted a survey with Florida school librarians in October, 2012. The researcher promoted the research among the members of the Florida Association for Media in Education (FAME) and recruited 170 school librarians from both primary and secondary schools $(\mathrm{K}-12)$.

There were two questions regarding professional development methods and the questionnaires allowed for multiple responses. The first question-inquiring about anticipated professional development methods-obtained 568 answers from 160 participants. The second question asked about preferred professional development methods and obtained 462 answers from 158 participants.

\section{Data Analysis}

The researcher investigated two survey questions and identified the gap between anticipated and preferred methods of professional development:

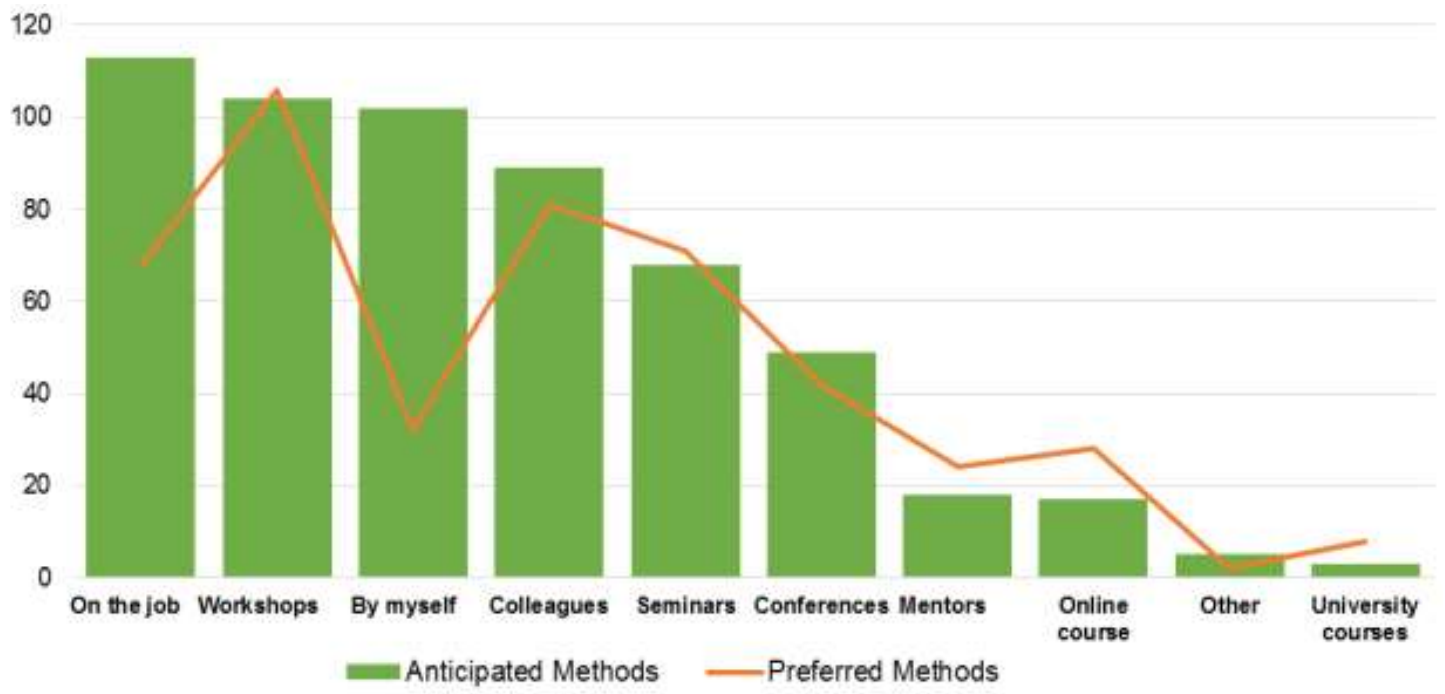

Figure 2: Anticipated and preferred professional development methods

\section{What method do school librarians prefer for professional development regarding digital textbooks?}

Regarding the preferred way to be educated about digital textbooks, the survey found that $22.9 \%(n=106)$ of responses preferred "county or school-based workshops." Workshops are considered a very hands-on way for school librarians to plunge into discussion, and are the best method to build networking (Harvey, 2012). Analysis thus suggests that school librarians need more in-depth meetings to interact with other school librarians.

Of the responses, $17.5 \%(n=81)$ preferred "colleagues or study groups with colleagues", $15.4 \%(n=71)$ "professional seminars including webinars", and 9.1\% $(n=42)$ preferred "conferences." These high-ranked methods consist of $64.9 \%$ of all responses, indicating that school librarians prefer to be educated in a collaborative way. The six methods that got lower answers, suggest that school librarians have low interest in being educated as follows: 
$14.7 \%(n=68)$ "on the job",6.9\% $(n=28)$ "by myself", $6.1 \%(n=28)$ "online course", $5.2 \%$ $(n=24)$ "mentors", $1.7 \%(n=8)$ "university campus-based courses", and $0.4 \%(n=2)$ "other" methods.

What do school librarians anticipate for professional development regarding digital textbooks?

The second question pertains to which methods school librarians anticipate in order to educate themselves about digital textbooks based on their previous experience. Unlike the answers about their 'preferred' way, the answers for anticipated professional development methods are more concentrated. The highest ranking method is "on the job" $(20.1 \%, n=113)$ indicating librarians expect to be educated on the job. The third highest method is "by myself" $(17.2 \%, n=97)$. These two methods describe modern school librarians' working environment as solo librarians who work independently.

The traditional methods are as follows: "county or school-based workshops" (18.5\%, $n=104)$, "colleagues or study groups with colleagues" $(15.8 \%, n=89)$, "professional seminars including webinars" (12.1\%, $\mathrm{n}=68)$ and "conferences" $(8.7 \%, \mathrm{n}=49)$.

\section{Gap between anticipated way and preferred way}

Statistical analysis confirms that school librarians express strong disagreement between the anticipated and preferred ways. The researcher entered the statistical data into Statistical Package for the Social Science (SPSS) version 21.0. The anticipated percentage of each method differs by the expectation percentage: $X^{2}(1, N=1025)=42.503, p=.00$. Figure 2 indicates the percentage gaps between anticipated and preferred methods.

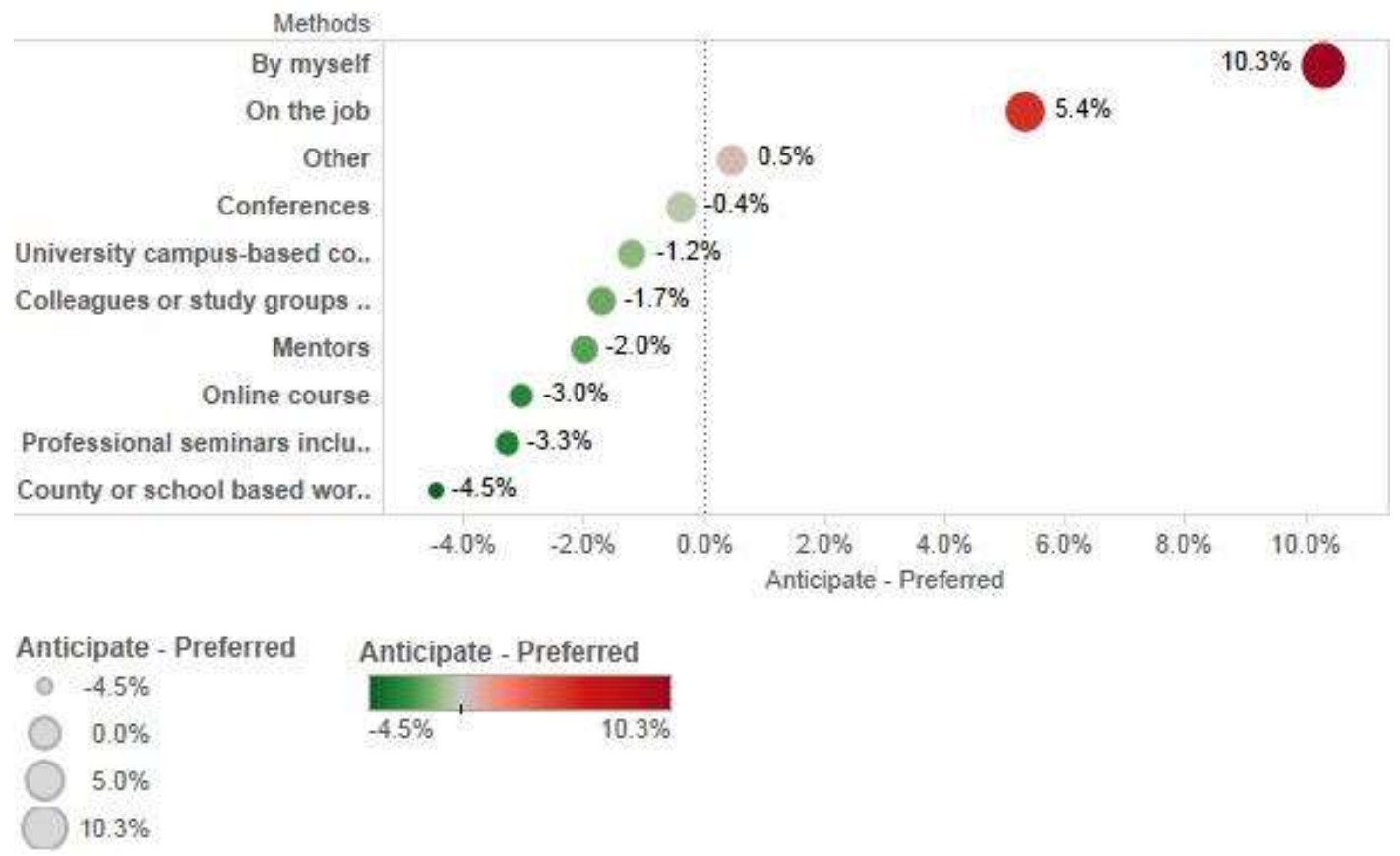

Figure 3: The gap between anticipation and preference

Among the ten items, "by myself" has the biggest gap (10.3\%). It means that the selfeducation is the way that school librarians did not want to have, but they anticipated that they 
would have most. As another indicator of self-education, "on the job" received $5.4 \%$, indicating that more school librarians anticipated that they would educate themselves during their jobs. On the other hand, $4.5 \%$ more school librarians preferred "county or school based workshops" for their professional development, and 3.3\% of school librarians preferred "professional seminars including webinars". Although a small number of participants chose "online course", $3 \%$ more librarians selected "online courses" for their preferred method of professional development.

\section{Conclusion and Suggestions}

Although the previous literature has indicated that professional development, and the methods by which that is accomplished, are significant for the integration of technology in schools, there has been no discussion about how to provide professional development for school librarians in integrating digital textbooks. In order to stimulate discussion on this subject, this study identifies both preferred and anticipated methods of professional development and the gap between them. It has been found that school librarians wish to initiate their training with other colleagues through workshops and study groups, which will enable them to discuss digital textbooks, and build networks with respect to the new technology. This result is consistent with Kang and Everhart's (2014) research. Since school librarians' most significant stage of concern is Stage 0 , Unconcerned, and most of them have lower stages of concern (unconcerned, personal and informational stages), they will require consultations and discussions about digital textbooks in order to understand their importance. However, the anticipated method reflects the environment of the solo librarian, who is likely to receive professional development alone or on the job. These two methods differ greatly. Because school librarians are largely not yet interested in the implementation of digital textbooks, it is worth noting that professional development should address not only technical skills, but also school librarians' beliefs and attitudes (Hixon \& Buckenmeyer, 2009).

Digital textbooks will be embraced in the next school year, and school librarians, who are leaders in technology integration, still express lower stages of concern about the subject. In order to help school librarians play their part by creating new services, collaborating with other educators, and celebrating this new technology, professional development that will enlarge their viewpoint and enhance their awareness of the need for methods of implementation of digital textbooks, is urgently required.

\section{References}

American Association of School Librarians. (2009). Empowering learners: Guidelines for school library media programs. Chicago: American Association of School Librarians.

Branch-Mueller, J., \& De Groot, J. (2011). The power of Web 2.0: Teacher-librarians become school technology leaders. School Libraries Worldwide, 17(2), 25-41.

Claesgens, J., Rubino-Hare, L. L. h. n. e., Bloom, N., Fredrickson, K., Henderson-Dahms, C., Menasco, J., \& Sample, J. (2013). Professional development integrating technology: Does delivery format matter? Science Educator, 22(1), 10-18. 
Everhart, N., Mardis, M., \& Johnston, M. P. (2012). National Board Certified school librarians' leadership in technology integration: Results of a national survey. School Library Media Research, 14, 1-19.

Fletcher, G., Schaffhauser, D., \& Levin, D. (2012). Out of print: Reimagining the K-12 textbook in a digital age. Washington, DC: The State Educational Technology Directors Association (SETDA).

Foote, C. (2013). From professional development to personalized learning. Library Media Connection, 31(4), 34-35.

Harvey, C. A. (2012). Adult learners: Professional development and the school librarian. Santa Barbara, California: Libraries Unlimited, an imprint of ABC-CLIO, LLC.

Hixon, E., \& Buckenmeyer, J. (2009). Revisiting technology integration in schools: Implications for professional development. Computers in the Schools, 26(2), 130146. doi: $10.1080 / 07380560902906070$

Johnston, M. P. (2012). Connecting teacher librarians for technology integration leadership. School Libraries Worldwide, 18(1), 18-33.

Kampylis, P., Law, N., Punie, Y., Bocconi, S., Brečko, B., Han, S., . . Miyake, N. (2013). ICT-enabled innovation for learning in Europe and Asia. Retrieved from http://ftp.jrc.es/EURdoc/JRC83503.pdf doi:10.2791/25303

Kang, J. H., \& Everhart, N. (2014). Digital textbooks: School librarians' stages of concerns in initial implementation. Information Research, 19(2), paper 625. Retrieved from http://InformationR.net/ir/19-2/paper625.html

Lankford, M. D. (2006). Leadership and the school librarian: Essays from leaders in the field. Worthington, Ohio: Linworth Pub.

Mardis, M., Everhart, N., Smith, D., Newsum, J., \& Baker, S. (2010). From paper to pixel: Digital textbooks and Florida's schools. Tallahassee, FL: PALM (Partnerships Advancing Library Media) Center.

Muijs, D., \& Harris, A. (2007). Teacher leadership in action: Three case studies of contrasting schools. Educational Management Administration \& Leadership, 35(1), 111-134. doi: $10.1177 / 1741143207071387$

Murray, M. C., \& Perez, J. (2011). E-textbooks are coming: Are we ready? Issues in Informing Science \& Information Technology, 8, 49-60.

Perez, L. (2010). The Role of school librarians in promoting the use of educational technologies. Teacher Librarian, 38(1), 72-73.

Perez, L. (2013). Master librarian. Knowledge Quest, 41(4), 22-26. 
Starkey, C. J. (2012). Releasing your inner leader. Knowledge Quest, 40(3), 10-13. The Florida Senate. (2011). SB 2120: K-12 Education Funding. Retrieved from http://www.flsenate.gov/Session/Bill/2011/2120

The Korea Education and Research Information Service (KERIS). (2009). Digital Textbook. Retrieved from http://www.dtbook.kr/renew/english/index.htm

\section{Biographical note}

Ji Hei Kang is a doctoral candidate at the School of Information within the College of Communication and Information at Florida State University (FSU), USA. The main topic that she focuses on is school librarians' leadership role in implementing technological innovations. For her dissertation project, she is conducting research analyzing school librarians' Stages of Concern in employing digital textbooks. She plans to follow up her research by applying a qualitative method to identify school librarians' Level of Use of digital textbooks. She is also interested in studying how librarians promote new types of educational technology, such as mobile augmented reality and big data, in theory and practice. She can be contacted at jk11e@my.fsu.edu. 